J. Clin. Chem. Clin. Biochem.

Vol. 14, 1976, pp. 577-579

\title{
The Composition of Gallstones from Geriatric Patients Methods for the Determination of Cholesterol and of Black Substances in Gallstones
}

By A. Uldall, C. Petri and T. Geill

\section{Geriatric Unit, De Gamles By, Copenhagen, Denmark}

(Received May 31, 1976)

Summary: 78 female and 31 male Danish gallstone cases found by autopsy were studied. The mass of the gallstone(s) from each patient was recorded and the stones were ground. The content of cholesterol in the mixed material from each patient was determined, using the Liebermann-Burchard reaction. The ratio Gallstone(s) ash - mass/Gallstone(s) - mass was determined, and where this ratio exceeded 0.10 , calcium and phosphate determinations were carried out. Subjective description of the stones as 'mixed stones' or 'pigment stones' was substituted by visual comparison of the ground gallstones with a 'grey scale' (black was given the highest value). The values of this quantity and the ash values generally increased with a decreasing content of cholesterol. The content of cholesterol in the gallstones increased with increasing stone mass. The chemical composition of gallstones found by surgery seems to differ from that of gallstones found by autopsy.

\section{Die Zusammensetzung von Gallensteinen geriatrischer Patienten. Methoden zur Bestimmung von Cholesterin und schwarzen Substanzen in Gallensteinen}

Zusammenfassung: Die bei der Autopsie gefundenen Gallensteine von 78 weiblichen und 31 männlichen dänischen Patienten wurden untersucht. Das Gewicht der Gallensteine jedes Patienten wurde festgestellt. Die Steine wurden gemahlen. Der Cholesteringehalt wurde in dem gemischten Material eines jeden Patienten mit der Liebermann-BurchardReaktion bestimmt. Das Verhältnis Aschegewicht der Gallensteine/Rohgewicht der Gallensteine wurde bestimmt; Calcium- und Phosphatbestimmung wurden durchgeführt, wenn das Verhältnis 0,10 überschritt. Die subjektive Beschreibung der Steine als ,gemischte Steine“ oder „Pigmentsteine“ wurde ergänzt durch visuellen Vergleich der gemahlenen Gallensteine mit einer Grauskala (schwarz ergibt den höchsten Wert). Diese Werte und der Aschegehalt stiegen generell mit fallendem Cholesteringehalt der Steine an. Der Cholesteringehalt der Gallensteine stieg mit steigendem Steingewicht. Die chemische Zusammensetzung von Gallensteinen, die bei der Operation gefunden wurden, scheint sich von der bei Autopsie gefundener Gallensteine zu unterscheiden.

\section{Introduction}

Few papers describing the chemical composition of human gallstones have been published. The main component in gallstones is usually cholesterol. In Germany the substance content of cholesterol in gallstones from most patients was above $2.33 \mathrm{~mol} / \mathrm{kg}$ (1) (the substance content of cholesterol in chemically pure cholesterol is $2.59 \mathrm{~mol} / \mathrm{kg}$ ); in one out of 100 cases the substance content was as low as $0.26 \mathrm{~mol} / \mathrm{kg}$. The average substance content of cholesterol in 331 gallstones from 8 countries was $1.81 \mathrm{~mol} / \mathrm{kg}$ (2); most of the residual part of the gallstones consisted of calcium salts; sex differences and differences between countries with respect to the composition of gallstones was found. The present paper presents the composition of gall- stones from Danish geriatric patients and the methodologies used. The results are compared with similar material of German origin.

\section{Materials and Methods}

The study was carried out with gallstones found by autopsy of urban patients ( 78 female and 31 male cases) from the Geriatric Unit, De Gamles By. The age by the time of death varied between 67 and 99 with 84 years as the arithmetic mean value.

The mass of the gallstone(s) from each patient was recorded, the stone $(s)$ was ground and passed through a stainless steel sieve (holes $0.6 \times 0.6 \mathrm{~mm}$ ).

The fraction of black components in the mixed material from each patient was evaluated by visual comparison under 'daylight' from fluorescent tubes with an arbitrary 'grey scale' 
(1-6 arbitrary units), corrected for colour influence (3). Gallstone(s) material too dark to correspond to 6 arbitrary units in the scale was given the value 7 arbitrary units.

The ratio Ash - mass/Gallstone(s) - mass was determined according to standard procedure (4) as were the determination of the substance content of calcium(II) $(\mathrm{Ca})$ and of phosphate(P) $(5,6)$. The two latter determinations were only carried out on stones when the above ratio exceeded 0.1 .

The relative loss of mass after drying at $105^{\circ} \mathrm{C}$ (until stable mass) was recorded as the water content.

Cholesterol was extracted from about $125 \mathrm{mg}$ mass of the dried gallstone powder using $25.0 \mathrm{ml}$ chloroform saturated with a solution of sodium hydroxide (substance concentration $=5 \mathrm{~mol} / \mathrm{l}$ ) in deionized water. The extraction time was only $0.1 \mathrm{ks}$ (= approximately 2 minutes) in order to minimize the extraction of coloured substance, e. g. bilirubin, which increases the apparent cholesterol values. When the colour of the extract was more dense than that of a chloroform solution of bilirubin, substance concentration $=30 \mu \mathrm{mol} / 1$, the bilirubin was removed from the extract by washing with the above mentioned sodium hydroxide solution saturated with chloroform. The concentration of cholesterol in the chloroform extract was determined by a Liebermann-Burchard reaction according to Carr \& Drekter (7), using the procedure described by these authors under 'Standard'; the volume of the cholesterol solution (cholesterol dissolved in glacial acetic acid) was replaced by the chloroform extract. The calibration of the method was based on 'Standard Reference Material 911, Cholesterol' from the United States' Bureau of Standards. The other reagents were pro analysi grade from Merck, Darmstadt. A pool of gallstones (cholesterol, substance content $=2.10 \mathrm{~mol} / \mathrm{kg}$ ) was run as a control through the 27 main series of the analyses and the relative standard-deviation for this group was 0.012 .

All analytical results refer to the undried gallstone(s) material.

\section{Quantities and units}

A quantity is discribed with the format System-Component, kind of quantity $=$ numerical value $X$ unit; if the system is idential with the Component the latter is omitted in order to avoid repetitions. In the table the heading is given the form $\frac{\text { quantity }}{\text { unit }}$ so that only numerical values are given in the field.

\section{Results}

Table 1 shows the results grouped according to the substance content of cholesterol in the gallstones. With an increasing substance content of cholesterol the arbitrary substance content of black component and the mass fraction of water decrease, as well as the ratio between the ash mass and the mass of the gallstones; simultaneously the mass of the gallstones increases.

The calcium(II) and phosphate investigation shows 10 patients with no or small amounts of phosphates in their calcium(II) containing stones. 5 additional patients had mixtures of phosphate free calcium salts and some calcium phosphates e. g., 'apatite' $\left(\mathrm{Ca}_{10}\left(\mathrm{PO}_{4}\right)_{6}(\mathrm{OH})_{2}\right)$. Three further patients showed results which correspond to nearly pure 'apatite'. One patient had much more phosphate than could be bound by the amount of calcium(II) found; this abnormal stone contained nearly no cholesterol and was quite white.

The number of gallstones from each patient varied between 1 and more than 50; the figures, however, showed no correlation to other results of this investigation.

Tab. 1.109 gallstone patients grouped according to the substance content of cholesterol in their stones $\left.\left.\left.{ }^{a}\right),{ }^{b}\right),{ }^{c}\right)$.

\begin{tabular}{|c|c|c|c|c|c|c|c|c|c|c|c|c|c|}
\hline \multirow{2}{*}{\multicolumn{2}{|c|}{$\begin{array}{l}\text { Gallstone(s) - } \\
\text { Cholesterol, } \\
\text { substance content }\end{array}$}} & \multirow{2}{*}{\multicolumn{2}{|c|}{$\begin{array}{l}\text { Number of } \\
\text { patients }\end{array}$}} & \multirow{2}{*}{\multicolumn{7}{|c|}{$\begin{array}{l}\text { Number of patients/l having values of Gall- } \\
\text { stone(s) - Black component, arbitrary } \\
\text { substance content }\end{array}$}} & \multirow{3}{*}{$\begin{array}{l}\text { Gall- } \\
\text { stone(s)- } \\
\frac{\text { mass }}{\mathrm{g}} \quad \because\end{array}$} & \multirow{3}{*}{$\begin{array}{l}\text { Gallstone(s) - } \\
\text { - Water, } \\
\text { mass fraction } \\
1\end{array}$} & \multirow{3}{*}{$\begin{array}{l}\text { Gallstone(s) } \\
\frac{\text { ash }- \text { mass }}{\text { Gallstone(s) - mass }}\end{array}$} \\
\hline & & & & & & & & & & & & & \\
\hline $\mathrm{mol} / \mathrm{kg}$ & & \multicolumn{2}{|l|}{1} & \multicolumn{7}{|c|}{ arbitrary units } & & & \\
\hline interval & $\begin{array}{l}\text { recorded } \\
\text { mean }\end{array}$ & male & $\begin{array}{l}\text { fe- } \\
\text { male }\end{array}$ & 1 & 2 & 3 & 4 & 5 & 6 & 7 & mean & mean & mean \\
\hline $0.00-0.25$ & 0.10 & 3 & 6 & 1 & - & - & - & 1 & 5 & 2 & 2.26 & 0.0748 & 0.2331 \\
\hline $0.26-1.02$ & 0.56 & 2 & 4 & - & - & - & - & 2 & 4 & - & 3.23 & 0.0210 & 0.1065 \\
\hline $1.03-1.54$ & 1.27 & 3 & 5 & - & - & - & 1 & 4 & 3 & - & 2.99 & 0.0173 & 0.1579 \\
\hline $1.55-2.06$ & 1.92 & 2 & 10 & - & - & - & 3 & 9 & - & - & 4.65 & 0.0111 & 0.1081 \\
\hline $2.07-2.32$ & 2.21 & 3 & 12 & - & - & 1 & 8 & 6 & - & - & 7.40 & 0.0070 & 0.0783 \\
\hline $2.33-2.58$ & 2.49 & 10 & 25 & 1 & 6 & 7 & 20 & 1 & - & - & 8.74 & 0.0078 & 0.0216 \\
\hline $2.59-2.75$ & 2.65 & 8 & 16 & $\overline{6}$ & 4 & 10 & 4 & - & - & - & 8.22 & 0.0063 & 0.0069 \\
\hline
\end{tabular}

a) Table with results from the individual patients will be supplied on request.

b) Determination of the substance contents of calcium(II)(Ca) and phosphate(P) in the gallstones was carried out in 19 cases where the ash values exceeded 0.10 (this limit was exceeded in 25 cases; however, in only 19 cases a sufficient amount of gallstone material was available for the determinations). The calcium values were found to be between 0.96 and $4.12 \mathrm{~mol} / \mathrm{kg}$. In $1.0 \mathrm{cases}$ the phosphate values were less than $0.1 \mathrm{~mol} / \mathrm{kg}$, in 8 cases the phosphate values were between 0.51 and $1.04 \mathrm{~mol} / \mathrm{kg}$ and the substance ratios, phosphate(P)/calcium(II)(Ca) were between 0.15 and 0.58 . In one case the phosphate value was $4.05 \mathrm{~mol} / \mathrm{kg}$ and the substance ratio, phosphate(P)/calcium(II)(Ca) was 1.37 .

c) A group of gallstone patients having almost only cholesterol in their gallstones is recognised, using Gallstone(s) - Cholesterol, substance content $=2.325 \mathrm{~mol} / \mathrm{kg}$ as the threshold value. In fourfold tables this group is compared to the residual gallstone patients with respect to Gallstone(s) - Black component, arbitrary subtance content and Gallstone(s) - mass and Gallstone(s) - Water, mass fraction and Gallstone(s) ash - mass/Gallstone(s) - mass using 3.5 arbitrary units, $10 \mathrm{~g}, 0.015$ and 0.05 respectively as borderlines in order to divide the results for each type of quantity into two groups. Significantly unequal distribution of the results was found in all fourfold tables $(P \leqq 0.0005$ to $P \leqq 0.005)$. 


\section{Discussion}

In approximately one fourth of the gallstone cases the cholesterol values exceeded $2.59 \mathrm{~mol} / \mathrm{kg}$ which is the substance content of cholesterol in the pure compound. A lack of specificity of the Liebermann-Burchard reaction when used on biological material is found by other authors $(8,9)$. The substance content of 7 -dehydrocholesterol in selected gallstones was estimated and the presence of this component cannot fully explain the hyperestimation of cholesterol by the LiebermannBurchard reaction. A similar lack of specificity was found when the $\mathrm{H}_{2} \mathrm{SO}_{4}+\mathrm{FeCl}_{3}$-reaction was used on the gallstones.

In classical anatomic pathology the gallstones are described according to their appearance by terms such as 'mixed stones' and 'pigment stones'. This subjective description gives only little chemical information. The present paper shows a simple but more refined technique, the visual comparison of ground gallstones with a grey scale; increasing content of black compounds in the gallstones is found to correspond well with a decreasing content of the white component, cholesterol. Only 1 out of 109 gallstone patients showed a disagreement between the grey scale and the cholesterol content, and this stone material was dominated by calcium(II) and phosphate. Thus when the grey scale evaluation is to be used the desirability of an ash determination should also be considered.

The increasing mean values of the Gallstone(s) - mass with an increasing proportion of cholesterol is as yet unexplained, but it should be taken into account in future theories on the formation of gallstones.
The present autopsy material is compared to a similar German material (1), to a German surgery material (2) and to surgery material from 8 countries in 5 continents (2). For women only minor differences in the cholesterol results between countries and between gallstones obtained by autopsy and by surgery are found; for men the values in the surgical material are lower than in the autopsy material and significantly lower than in women. Less calcium(II) is found in the two autopsy materials than in the surgery material; this observation seems also valid for the phosphate results for women, however, the very low values in the German autopsy material are remarkable. It should be noted that different methodologies were used for the two groups of autopsy patients and for the surgery patients; however, it seems reasonable to expect a somewhat different chemical composition of the gallstones found by surgery and those found by autopsy, as the latter were accompanied only by minor or no clinical manifestations (silent stones). A table comparing the above autopsy and surgery gallstones will be supplied upon request.

\section{Acknowledgements}

The authors are indebted to professor Henrik Dam $\dagger$ (Technical University, Copenhagen) and to dr. Else Hove, M. D. (Country Hospital, S $\phi$ nderborg) for inspiring discussions. The authors wish to thank dr. Willy Hjarde, D. Sc. (National Food Institute, Copenhagen) who kindly performed the ash determinations. Mr. Laurids Rotb申ll Pedersen, M. Sc. Pharm. is thanked for the cholesterol determination using the $\mathrm{H}_{2} \mathrm{SO}_{4}+\mathrm{FeCl}_{3}$-reaction. Finally, the authors wish to thank ms. $A n y H \phi j$, medical technician, for her careful analytical work.

\section{References}

1. Klein, H. \& Fischer, W. (1956), Zèntralbl. Allg. Pathol. Pathol. Anat. 95, 360-365.

2. Sutor, D. J. \& Wooley, S. E. (1971), Gut 12, 55-64.

3. Kornerup, A. \& Wanscher, J. H. (1969), Farver i farver (Colours in coloured print), Politikens Forlag, Copenhagen.

4. Nordisk Metodik-Komite for Næringsmidler (1952) nr. 7, Teknisk Forlag, Copenhagen.

5. Nordisk Metodik-Komite for Næringsmidler (1955) nr. 21, Teknisk Forlag, Copenhagen.
6. Nordisk Metodik-Komite for Næringsmidler (1954) nr. 16, Teknisk Forlag, Copenhagen.

7. Carr, J. J. \& Drekter, I. J. (1956), Clin. Chem. 2, 358-368.

8. Henry, R. J. (1965), Clinical Chemistry: Principles and Technics, Harper and Row, Publishers, New York, 860.

9. Nakayäma, F. (1971), J. Lab. Clin. Med., 77, 366-377.

Lic. pharm. Adam Uldall Department of Clinical Chemistry Herlev Hospital University of Copenhagen Herlev Ringvej DK-2730 Herlev Denmark 


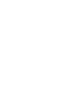

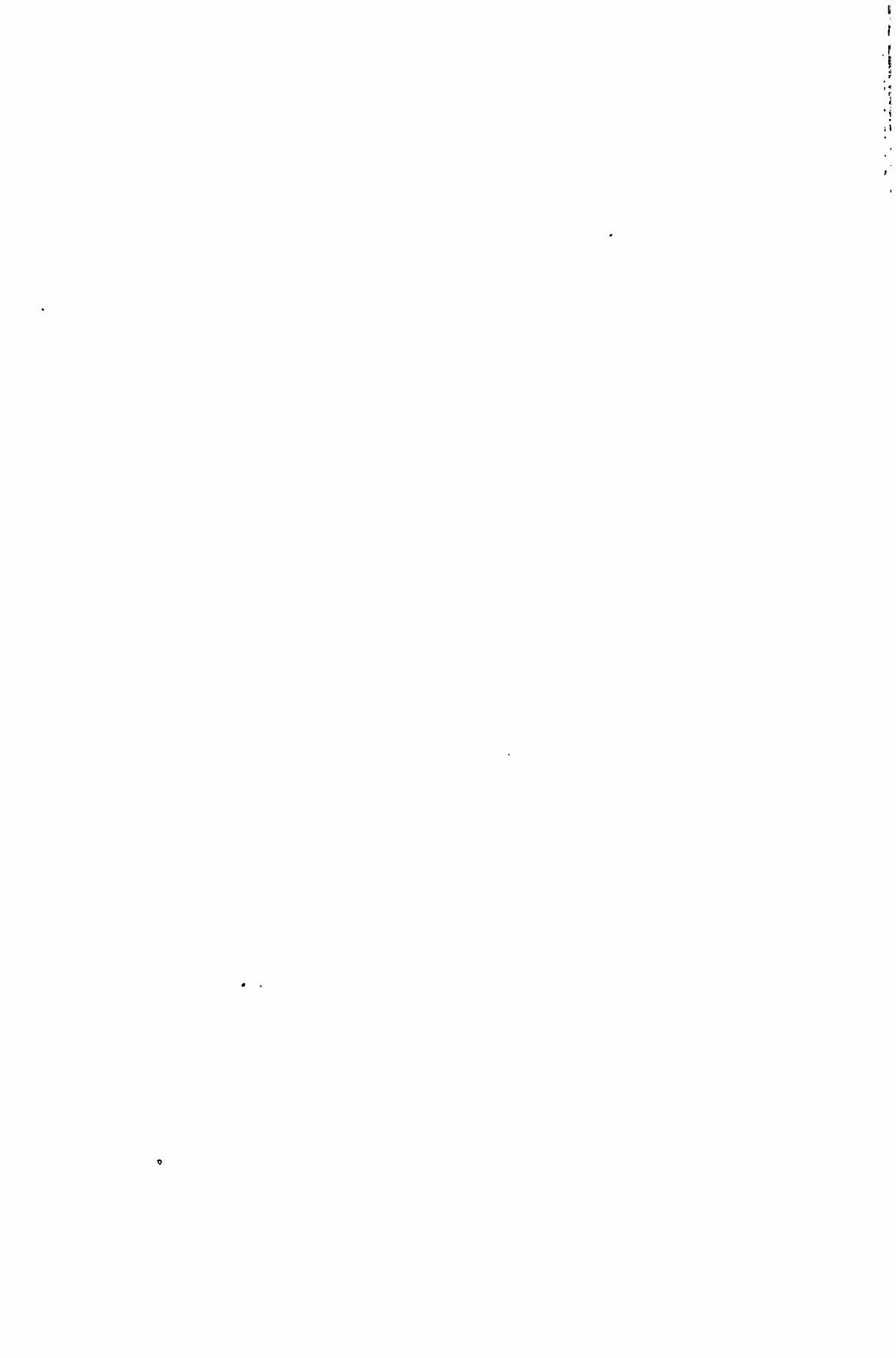

